\title{
PENGARUH PENDIDIKAN KEWARGANEGARAAN DALAM MEMBANGUN KARAKTER GENERASI MUDA
}

\author{
Shafarina Nidaul Aulia \& Dinie Anggraenie Dewi \\ Universitas Pendidikan Indonesia \\ shafarina@upi.edu
}

\begin{abstract}
Abstak
Keberadaan suatu negara diakui berdasarkan karakter yang dimilikinya. Hanya negara yang memiliki karakter kuat dan mendalam yang mempu menunjukkan bangsanya sebagai bangsa yang merdeka. Dengan demikian, penelitian ini bertujuan memberika gambaran mengenai pengaruh Pendidikan Kewarganegaraan dalam membangun karakter generasi muda dan pengimplemen-tasiannya dalam kehidupan sehari-hari. Metode penelitian menggunakan pendekatan kualitatif dengan metode survey menggunakan kuisioner. Informan penelitian yaitu siswa dan Mahasiswa berusia 17 sampai dengan 20 tahun. Hasil penelitian menunjukkan jika pengimplementasian karakter yang terbentuk dari Pendidikan Kewarganegaraan telah berhasil dilakukan oleh generasi muda. Beberapa karakter yang dituju adalah religius, demokratis, disiplin juga bertanggung jawab, berpikir kritis, dan peduli sesama.

Kata kunci: Pendidikan Kewarganegaraa, karakter, generasi muda
\end{abstract}

\begin{abstract}
The existence of a country is recognized based on its character. Only a country that has a strong and deep character is able to show its nation as an independent nation. Thus, this study aims to provide an overview of the influence of Citizenship Education in building the character of the younger generation and its implementation in everyday life. The research method used a qualitative approach with a survey method using a questionnaire. Research informants were students and students aged 17 to 20 years. The results show that the implementation of the characters formed from Citizenship Education has been successfully carried out by the younger generation. Some of the targeted characters are religious, democratic, disciplined as well as responsible, critical thinking, and caring for others.
\end{abstract}

Key words : Citizenship education, character, young generation

\section{PENDAHULUAN}

Negara Indonesia memiliki seja- rah yang berbeda dengan negara lainnya, karena Negara Kesatuan Republik Indonesia telah beberapa kali mengalami masa penjajalan, masa per- juangan melawan penjajah dan masa perjuangan yang terus berlanjut dalam mengisi kemerdekaan atau pada masa orde lama dan orde baru. Rakyat Indo- nesia memiliki berbagai kisah disetiap perjuangannya, karena sudah pasti problematika atau permasalahan yang terjadi disetiap masa akan berbeda- beda, tentunya perjuangan yang harus dilakukanpun pasti berbeda. Contoh- nya saja permasalahan perampasan sumber daya alam dan sumber daya manusia yang menjadi ciri perjuangan bangsa Indonesia pada masa per- juangan menghadapi kolonialisme.

Pada saat itu rakyat Indonesia penuh dengan semangat perjuangan hingga akhirnya membentuk suatu karakter yang menjiwai rakyat Indonesia pada saat itu, yaitu berjiwa patriotisme dan rela berkorban yang sangat besar untuk merebut kemerdeka-an bangsa Indonesia. Indonesia telah mengalami ke- merdekaan, pada masa ini bangsa Indo- nesia tetap melakukan suatu per- juangan, yaitu perjuangan untuk membangun karakter bangsa. Salah satu cara yang bisa dilakukan utuk mem- bangun karakter bangsa adalah melalui pendidikan. Bangsa Indonesia berharap dengan adanya pendidikan ini bisa menciptakan generasi yang cerdas dan 
berkarakter sesuai dengan Pancasila dan UUD Negara Republik Indonesia Tahun 1945. Pada setiap masa, bangsa Indonesia akan melahirkan calon-calon penerus bangsa yang akan meneruskan perjuangan. Untuk menciptakan gene- rasi muda yang berkarakter ini tidak bisa diperoleh secara tiba-tiba, namun harus melewati berbagai proses yang terus disesuaikan dengan keadaan dan tan-tangan yang ada pada setiap zamannya.

Bangsa Indonesia tentunya memi- liki jati diri bangsa yang sangat filosofis, dimana Pancasila yang men- jadi pemeran dalam ideologi dan juga pandangan hidup memiliki makna yang sangat mendalam, nilai ideologi yang terkandung dalam Pancasila bisa menyeimbangkan antara kehidupan yang bersifat individual dan yang bersifat sosial masyarakat. Salah satu cara untuk merealisasikan peran dan fungsi Pancasila yang dapat membentuk karakter generasi muda adalah degan Pendidikan Kewarganegaraan.

Menurut Kaelan (2010) yang dikutip oleh Izma, T.dkk.(2019) dalam Jurnal Wahana Didaktika Vol.17 No.1 Januari 2019 : 84-92, menyebutkan jika Pendidikan Kewarganegaraan diberi- kan kepada peserta didik untuk men- jadikan mereka sebagai warga negara Indonesia yang baik. Peran Pendidikan Kewarga-negaraan adalah berupaya dalam pembangunan dan pengem- bangan karakter generasi muda yang bisa membentuk generasi muda yang unggul dan berkarakter sesuai dengan nilai-nilai dasar Pancasila dan UUD Negara Republik Indonesia tahun 1945.

\section{Pendidikan}

Kewarganegaraan mempunyai peran yang sangat penting bagi pembentukkan karakter generasi muda (Nurgiansah, 2021b). Dalam UndangUndang No.20 Tahun 2003 tentang sistem Pendidikan Nasional, menyatakan jika pada setiap jenis, jalur, juga jenjang pendidikan, wajib memuat pelajaran yang terdiri dari
Pendidikan Bahasa, Pendidikan Agama, dan Pendidikan Kewarganega- raan. Dalam Undang-Undang tersebut sudah sangat jelas tertera jika Pendidi- kan Kewarganegaraan merupakan mata pelajaran yang wajib diajarkan di setiap jenjang pendidikan. Itu artinya urgensi Pendidikan Kewarganegaran sangatlah dijunjung tinggi oleh bangsa Indonesia.

Menurut peraturan Menteri Pendidikan Nasional nomor 22 tahun 2006 tentang standar isi untuk satuan pendidikan dasar dan menengah menyebutkan jika definisi dari Pendidikan Kewarganegaraan adalah mata pelaja- ran yang memfokuskan pada pembentukan warga negara yang memahami dan mampu melaksanakan hak-hak dan kewajibannya untuk menjadi warga negara Indonesia yang cerdas, termpil, dan berkarakter sebagaimana yang telah diamanatkan dalam Pancasila dan UUD Negara Republik Indonesia Tahun 1945. Karakter merupakan wujud moralitas yang berkaitan dengan kepri- badian yang terbentuk sebagai hasil dari internalisasi sebagai dasar berpikir dan berperilaku, sehingga menimbulkan ciri khas pada individu tersebut (Nurgiansah, 2021c)

UU Sisdiknas Pasal 3 memaparkan "Pendidikan Nasional berfungsi mengembangkan dan membentuk watak serta peradaban bangsa yang bermanfaat dalam rangka mencerdas- kan kehidupan bangsa, bertujuan untuk berkembang-nya potensi peseta didik agar menjadi manusia yag beriman, dan bertakwa kepada Tuhan Yang Maha Esa, berakhlak mulia, sehat, berilmu, cakap, kreatif, mandiri, dan menjadi warga Negara yang demokratis serta bertanggung jawab." Dalam UndangUndang Sisdiknas ini dapat dilihat jika tujuan Pendidikan Nasional yang salah satunya ada dalam Pendidikan Kewarganegaraan pada intinya untuk membangun karakter bangsa. 


\section{METODE PENELITIAN}

Menurut Cogan (1999) yang dikutip oleh Resfira (2019) dalam Journal of Civic Education (ISSN:2622-237X) Volume 2 Nomor 2 2019, menyebutkan dalam mengartikan civic education sebagai suatu mata pelajaran dasar di sekolah yang dirancang untuk mempersiapkan warga ne- gara muda agar kelak setelah dewasa dapat berperan aktif dalam kehidupan bermasya-rakat. Penelitian ini menggunakan pene- litian kualitatif. Menurut Bogdan dan Taylor penelitian kualitatif merupakan penelitian yang menghasilkan data be- rupa kata-kata tertulis atau lisan dan perilaku yang dapat diamati dari objek penelitian. Teknik analisis data yang dilakukan untuk mencapai tujuan dari penelitian ini yakni metode analisis dis- tribusi frekuensi, yaitu mengolah data dengan berbagai perhitungan statistik sederhana misalnya jumlah, selisih dan persentase data.

Dasar penelitian yang digunakan dalam mendapatkan hasil pengaruh Pendidikan Kewarganegaraan dalam membangun karakter generasi muda ini adalah dengan survei. Metode survei yang digunakan untuk mendapatkan data berupa mengedarkan kuisioner (Nurgiansah, 2021a). Dengan melihat keadaan saat ini, juga keterbatsan jarak, peneliti memu- tuskan untuk menggunakan bantuan aplikasi google form. Dengan menggunakan aplikasi ini banyak sekali keuntungan yang bisa didapatkan yaitu lebih efektif, efisien, interaktif, serta meminimalkan penggunaan kertas.

Aplikasi google form ini berguna untuk menyebarkan kuisioner secara cepat dan luas melalui link yang dibagi- kan kepada informan yaitu 20 orang yang terdiri atas siswa dan mahasiswa berusia 17 hingga 20 tahun. Waktu pe- nelitian ini berlangsung pada bulan Maret 2021.

\section{HASIL PENELITIAN DAN PEMBAHASAN Hasil Penelitian}

Pada hakikatnya Pendidikan Kewarganegaraan ini adalah sebuah ben- tuk pendidikan yang diperuntukan bagi generasi penerus bangsa yang memiliki tujuan agar generasi penerus bangsa menjadi warga negara yang mempunyai pemikiran secara tajam dan sadar akan hak dan kewajibannya dalam hidup bermasyarakat, berbangsa dan bernegara, selain itu, Pendidikan Kewarganega- raan juga bertujuan untuk membangun kesiapan seluruh warga negara agar menjadi warga dunia (global society) yang cerdas dan berkarakter juga berbudi pekerti luhur.

\section{Pembahasan}

\section{Pemahaman Pendidikan Kewar- ganegaraan}

Pendidikan

Kewarganegaraan memiliki tujuan yang cukup luas. Tujuan Pendidikan Kewarganegaraan bukan sekedar mengajarkan atau menciptakan warga negara yang bisa tunduk dan pa- tuh terhadap negara, tetapi juga menga- jarkan bagaimana seorang warga negara harus memiliki sikap toleran dan man- diri. Salah satu tokoh yang membahas mengenai ini adalah David Kerr (1999:2), ia menyebutkan pada intinya, hal ini menunjukkan jika pendidikan kewarganegaraan dirumuskan secara luas untuk memenuhi proses penyiapan generasi muda yang nantinya akan mengambil peran juga bertanggung ja- wab sebagai warga negara (Nurgiansah, 2020).

Dari hasil penelitian yang sudah dilakukan mengenai pandangan objek peneliti terhadap Pendidikan Kewarganegaraan dapat disimpulkan dari jawaban 20 informan adalah mereka memandang jika Pendidikan Kewarga- negaraan merupakan mata pelajaran yang wajib ada 
dari jendang SD sampai dengan Perguruan Tinggi yang bertu- juan untuk membentuk karakter gene- rasi muda agar mencintai tanah air, demokratis, berjiwa nasionalis, dan ber- akhlah mulia yang berlandaskan Panca-sila.

Berdasarkan jawaban yang sudah diberikan oleh 20 informan bisa ditarik kesimpulan jika rata-rata generasi muda yang berusia 17 hingga 20 tahun sudah memahami mengenai apa yang disebut Pendidikan Kewarganegaraan dan juga memahami apa tujuan dari Pendidikan Kewarganegaraan dengan baik.

Pembentukan dan perkembangan mata pelajaran Pendidikan Kewarganegaraan di Indonesia sangatlah pan- jang. Dalam sejarahnya Pendidikan Kewarganegaraan di Indonesia telah mengalami perubahan dalam tatanan penamaan dan juga konten materinya. Perubahan tersebut terjadi pada tahun 1957 dengan nama Kewarganegaraan, pada tahun 1961 berubah menjadi Civics, tahun 1968 menjadi Pendidikan Kewargaan Negara, tahun 1975 menjadi Pendidikan Moral Pancasila, tahun 1994 menjadi Pendidikan Pancasila dan Kewarganegaraan, tahun 2004 dalam uji coba kurikulum 2004 menjadi Kewarganegaraan, dan yang terakhir pada tahun 2006 hingga saat ini menjadi Pendidikan Kewarganegaraan.

Menurut Santoso (2015) dalam Wibowo,A.P dan Margi Wahono (Jurnal Civic Volume 14 No.2) menyebutkan jika kurikulum pasti berubah, tidak akan ada kurikulum yang abadi, perbahan kurikulum mengikuti perubahan zaman, bukan berarti kuriku- lum yang salah, tetapi jika zaman berubah maka kurikulumpun harus berubah mengikuti perubahan zaman.Membangun Karakter dalam Pendidikan Kewarganegaran

Berdasarkan penelitian yang sudah dilakukan tentang pandangan informan terhadap keterkaitan antara Pendidikan Kewarganegaran dan Pendi-dikan Karakter menghasilkan angka 100\%, mereka sepakat jika Pendidikan Kewarganegaraan dan Pendidikan Karakter memiliki hubungan.

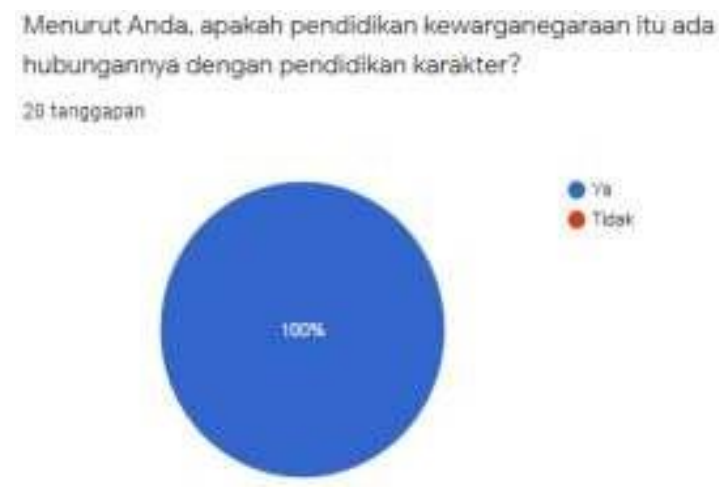

\section{Gambar 1. Hasil survey pandangan informan terhadap keterkaitan an- tara Pendidikan Kewarganegaran dan Pendidikan Karakter.}

Alasan mereka menyetujui adanya hubungan antara Pendidikan Kewarganegaraan dan Pendidikan Karakter ini dapat ditarik kesimpulan, mereka memiliki pendangan jika dalam Pendidikan Kewarganegaraan terdapat materi pembahasan yang dapat mengembangkan karakter generasi muda yang berlindaskan Pancasila dan mampu mengamalkannya dalam kehidupan bermasyarakat. Misi dan tujuan tersebut sejalan dengan pendapat yang yang dikemuka- kan oleh Supriyanto, 2018: 116 yang dikutip oleh Nurmalisa, Y. dkk ; 2020 dalam Jurnal Bhineka Tunggal Ika, Volume 07, Nomor 01, Mei 2020, mengenai hakikat dan tujuan pembelaja- ran Pendidikan Pancasila dan Kewarga- negaraan yaitu untuk mengembangkan peserta didik menjadi warga negara yang baik juga memiliki rasa kebanggaan terhadap Negara Kesatuan Republik Indo- nesia, juga cinta tanah air, jujur, disiplin, bertanggung jawab, santun, peduli, percaya diri dalam melakukan kegiatan untuk berinteraksi dengan 
lingkungan yang ada di sekitarnya.

\section{Implementasi Pendidikan Kewar- ganegaraan terhadap Karakter Generasi Muda}

Penelitian yang sudah dilakukan bertujuan untuk mengetahui apakah pembentukan karakter yang menjadi tujuan dari Pendidikan Kewarga- negaraan sudah bisa di implement- tasikan dalam kehidupan generasi muda atau belum. Beberapa karakter yang dituju adalah religius, demokratis, disiplin juga bertanggung jawab, berpikir kritis, dan peduli sesama.

Berikut adalah diagram per-sentase hasil penelitian mengenai im-plementasi penerapan karakter generasi muda.

\section{Apakah sebelum atau sesudah pembelajaran selalu melakukan kegiatan berdo'a?}

20 tanggapan

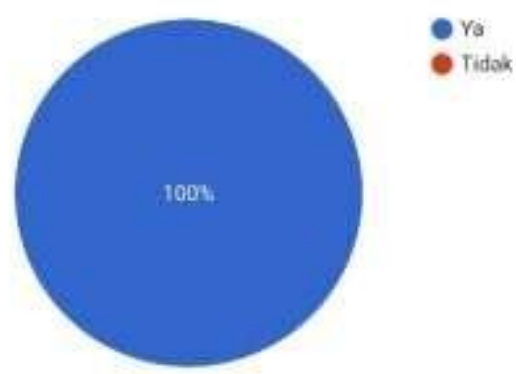

Gambar 2. Hasil survey mengenai implementasi karakter religius generasi muda.

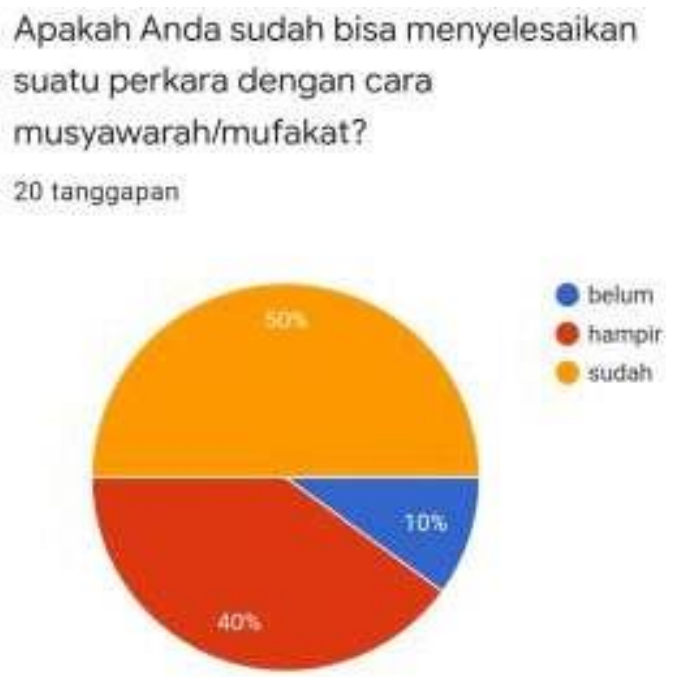

Gambar 3. Hasil survey mengenai implementasi karakter demokratis generasi muda.

Apakah Anda selalu mengerjakan tugas tepat waktu?

20 tanggapan

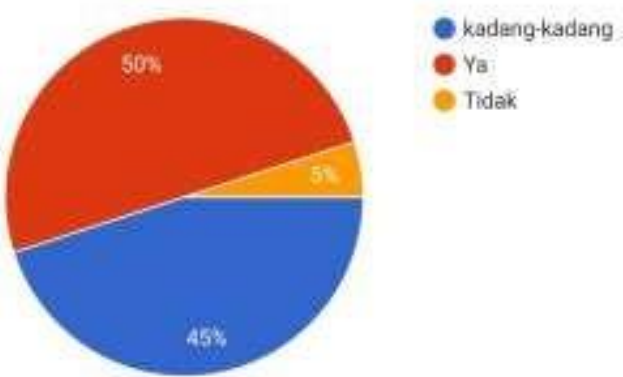

Gambar 4. Hasil survey mengenai implementasi karakter disiplin dan bertanggung jawab generasi muda. 
Ketika dalam pembelajaran ada hal yang tidak Anda mengerti, apakah Anda langsung bertanya kepada guru?

20 tanggapan

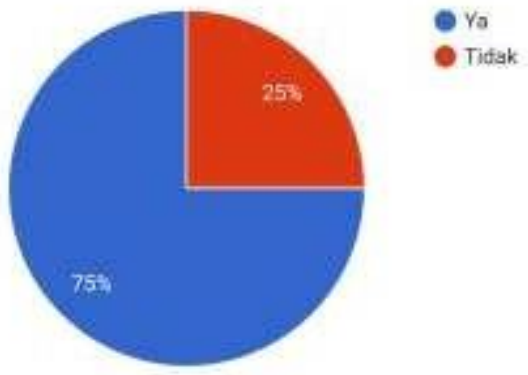

Gambar 5. Hasil survey mengenai implementasi karakter berpikir kritis generasi muda.

$$
\begin{aligned}
& \text { Apa yang akan Anda lakukan ketika melihat } \\
& \text { orang lain yang sedang kesulitan? } \\
& 20 \text { tanggapan }
\end{aligned}
$$

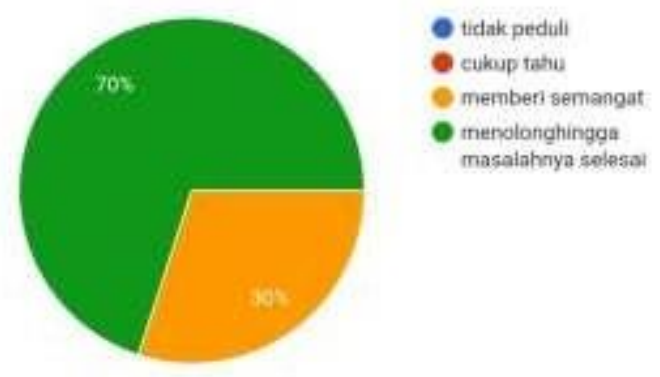

Gambar 6. Hasil survey mengenai implementasi karakter peduli sesama generasi muda.

Berdasarkan grafik presentase hasil survei tersebut dapat ditarik kesim- pulan jika karakter religius generasi mu- da sudah terealisasikan dengan hasil 100\% mereka selalu melakukan kegiatan berdo'a sebelum melaksanakan pembe- lajaran. Untuk karakter demokratis dalam menyelesaikan suatu permasala- han dari hasil survei terlihat ada keberagaman jawaban, namun sudah 50\% dari mereka bisa mengimplemen- tasikan kerakter yang demokratis, dan selisih antara yang sudah mampu dan belum mampu untuk mengimplementa- sikan karakter inipun bisa terbilang cu- kup jauh, rata-rata generasi muda sudah bisa mengimplementasikan karakter demokratis dengan cara menyelesaikan permasalahan secara bermusyawarah.

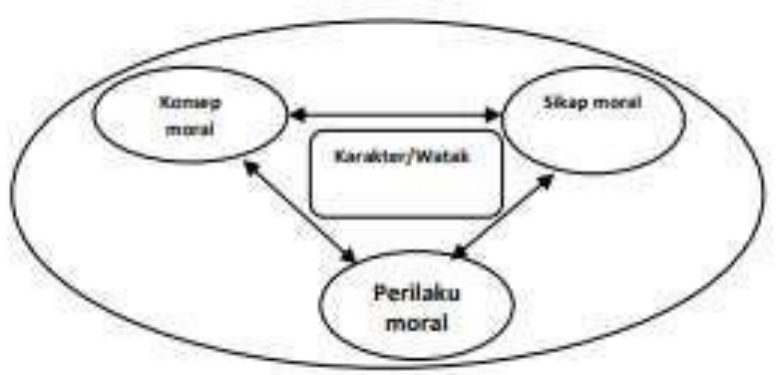

Untuk pengimplementasian karak- ter disiplin dan bertanggung jawab berdasarkan hasil survei pada umumnya sudah tercapai karena nilai persentase mereka yang mampu disiplin dalam mengerjakan tugas tepat waktu memiliki angka yang lebih besar dibandingkan yang tidak. Karakter selanjutnya adalah berpikir kritis, karakter inipun sudah sangat tercapai dengan adanya $75 \%$ jawaban yang menyatakan mereka selalu bertanya jika memang tidak mengerti tentang suatu hal, dan karakter yang terakhir adalah peduli sesama. Berdasar- kan hasil survei ratarata generasi muda sudah memiliki karakter peduli terhadap sesama, namun terdapat suatu perbeda- an, yaitu ada yang hanya memberikan se- mangat dan ada pula yang mampu mem- bantu sesama hingga permasalahnya se- lesai. Dari dua jawaban tersebut tidak ada yang salah, karena keduanya sudah memenuhi karakter peduli sesama. Penanaman Pendidikan Karakter bagi Generasi Muda

Perjuangan bangsa Indonesia pada setiap era selalu mengalami perbedaan. Dan saat ini yang menjadi permasalahan untuk diperjuangkan adalah pembunu- han nilai-nilai karakter generasi muda, oleh sebab itu di butuhkannya penana- man Pendidikan Karakter yang dilaku- kan secara serius dan terencana. 
Menurut Lickona dalam Sulistyarini (Jurnal Bhinneka Tunggal Ika, Volume 2, Nomor 1, Mei 2015) menyatakan jika karakter itu sangat berkaitan dengan konsep moral, sikap moral, dan perilaku moral. Berdasarkan ketiganya, jika suatu karakter yang baik didukung oleh pengetahuan dan niat melakukan perbuatan baik.

Menurut Megawangi (2004) dalam Sulistyarini (2015) disebutkan jika karakter di Indonesia ingin berkem- bang, maka terdapat 9 pilar yang sela- yaknya diajarkan pada generasi muda, yaitu :

1. cinta terhadap Tuhan

2. bertanggung jawan, disiplin, dan mandiri

3. jujur

4. sopan santun

5. saling menyayangi, peduli, dan kerjasam.

6. percaya diri, kreatif, berkerja keras, juga pantang menyerah

7. Adil dan Kepemimpinan

8. Rendah hati

9. Toleransi dalam persatuan

Jika 9 pilar ini dapat terpenuhi maka Pendidikan Karakter dapat dipahami dengan upaya yang sangat terencana untuk menciptakan peserta didik berkarakter unggul.

\section{KESIMPULAN}

Meningkatkan kualitas karakter bangsa merupakan salah satu upaya dari Pendidikan di Indonesia terutama Pendidikan Kewarganegaraan. Meningkatkan mutu warga melalui pendidikan merupakan salah satu upaya dari Pendidikan Kewarganegaraan. Sebagaimana yang diketahui jika pendidikan merupakan suatu hal yang sangat penting peranannya dalam membangun karakter bangsa terutama generasi muda yang akan menjadi menerus perjuangan bangsa. Kredibilitas dalam melakukan tindakan yang berbudi pekerti luhur sesuai dengan apa yang terdapat dalam Pancasila dan UUD Negara Republik Indonesia tahun 1945 bisa menciptakan suatu bangsa yang berkarakter, dan hal ini bisa didapat dari Pendidikan Kewarganegaraan dalam kehidupan. Generasi muda Indonesia yang berkarakter Pancasila saat ini sudah mulai terkikis oleh perkembangan zaman. Jika hal ini dibiarkan dapat meruntuhkan keyakinan masyara- kat jika bangsanya sudah tidak tangguh dan berkarakter kuat. Sehingga, dengan adanya Pendidikan Kewarganegaraan ini diharapkan mampu meningkatkan kesadaran masyarakat terutama generasi muda terhadap pertahanan dan pening- katan karakter bangsanya.

Saran yang bisa dilakukan untuk mewujudkan karakteristik warganegara yang tidak hanya baik tapi kuat dan tangguh tentu harus di imbangi dengan peran pendidik yaitu guru dan dosen dalam melaksanakan pembelajaran Pen- didikan Kewarganegaraan, terutama lebih meningkatkan pada sumber bahan ajar yang relevan dan yang dirasa dapat menambah dan meningkatkan aspek good citizen dalam diri siswa dan juga mahasiswa untuk menjalankan kehidupannya, sehingga dari pembelajaran Pendidikan Kewarganegaraan ini dapat diimplementasikan dengan baik dalam kehidupan berbangsa dan bernegara.

\section{DAFTAR PUSTAKA}

Aji, Purnomo Cahyo. (2018). Peran PKN dalam Membentuk Karakter Kewarganegaraan Melalui Pendekatan Berbasis Nilai di Perguruan Tinggi.

Fauzi, I. dan Srikantono. (2013). Pendidikan Kewarganegaraan (Civil Education). Jember : SUPERIOR “Pusat Studi Pemberdayaan Rakyat dan Transformasi Sosial”

Haqiqi, M.I. dkk.(2017). Karakter Tanggung Jawab dan Keterampilan Komunikasi Matematis 
pada Pembela- jaran Berpendekatan PMRI Berbantuan Scaffolding Materi Pecahan.

Izma, Tri,dkk.(2019). Peran Pendidikan Kewarganegaraan dalam Membangun Karakter

Bangsa. Diakses dari Jurnal Wahana Didaktika Vol. 17 No.1 Januari 2019 : 84-92

Nurgiansah, T. H. (2020). Filsafat Pendidikan. In Banyumas: CV Pena Persada.

Nurgiansah, T. H. (2021a). Pelatihan Penelitian Tindakan Kelas Bagi Guru Pendidikan

Kewarganegaraan Di Sekolah Menengah Atas Se-Kabupaten Bantul. BERNAS: Jurnal

Pengabdian Kepada Masyarakat, 2(1), 28-33. https://doi.org/10.31949/jb.v2i1.566

Nurgiansah, T. H. (2021b). Pendidikan Pancasila. In Solok: CV Mitra Cendekia Media.

Nurgiansah, T. H. (2021c). Petuah Pendidikan Kewarganegaraan Dalam Kontestasi Politik.

AoEJ: Academy of Education Journal, 12(1), 39-47.

Nurmalisa, Y. dkk. (2020). Peranan Pembelajaran Pendidikan Kewarganegaraan dalam membangun Civic Conscience. Diakses dari Bhineka Tunggal Ika: Kajian Teori dan Praktik PKn Volume 07, No. 1, Mei 2020, pp. 34-46

Omeri, N. (2015). Pentingnya Pendidikan Karakter dalam Dunia Pendidikan. Diakses dari Manajer Pendidikan, Volume 9, Nomor 3, Juli 2015, hlm. 464-468

Rachmah, H. (2013). Nilai-Nilai dalam Pendidikan Karakter Bangsa yang Berdasarkan Pancasila dan UUD 1945. Diakses dari E-Journal WIDYA

Ridhuan, S. (2016). Membangun Karakter Bangsa untuk Menciptakan Masyarakat yang Tangguh, Kompetitif, Berahlak Mulia, Bermoral dan Beretika Berdasarkan Pancasila. Diakses dari Muhamad Irwan Haqiqi, Scolastika Mariani \& Masrukan / JPE 6 (1) (2017): $21-2$

Resfira. (2019). Peran Pendidikan Kewarga Negaraan dalam Membangun Masyarakat Berjiwa Nasional. Diakses dari Journal of Civic Education (ISSN:2622-237X) Volume 2 Nomor 2 2019

Sulistyarini. (2015). Pengembangan Karakter Berbasis Panca-sila Melalui Pendidikan Kewarganegara-an. Diakses Dari Jurnal Bhinneka Tung-gal Ika, Volume 2, Nomor 1, Mei 2015.

UU No.20 Tahun 2003. Diakses dari https://peraturan.bpk.go.id/Home/Detail s/43920/uuno-20-tahun-2003

Wahyandari, W. (2014). Pendidikan Karakter Disiplin Di Sekolah Dasar. Diakses dari Cakrawala Pendidi- kan, Juni 2014, Th. XXXIII, No. 2

Wibowo, A.P dan Margi Wahono. (2017). Pendidikan Kewarganegaraan: Usaha Konkret untuk Memperkuat Multikulturalisme di Indonesia. Diakses dari Jurnal Civics Volume 14 Nomor 2, Oktober 2017

Wiyono, S.dkk.(2019). Kajian Nilai Ketuhanan Yang Maha Esa untuk Mengembangkan Karakter Anti Korupsi. Diakses dari Jurnal Civic Education: Media Kajian Pancasila dan Kewarganegaraan Vol. 3 No. 2 Tahun 2019 